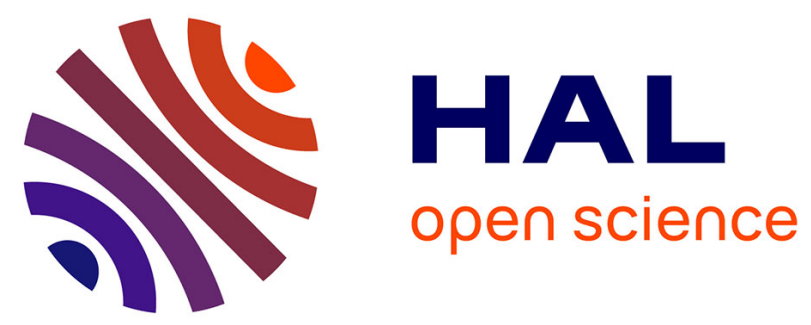

\title{
A role for antibodies in natural HIV control
}

\author{
Arnaud Moris, Mathias Pereira, Lisa Chakrabarti
}

\section{To cite this version:}

Arnaud Moris, Mathias Pereira, Lisa Chakrabarti. A role for antibodies in natural HIV control. Current Opinion in HIV and AIDS, 2019, 14 (4), pp.265-272. 10.1097/COH.0000000000000554 . hal-02172944

\section{HAL Id: hal-02172944 \\ https://hal.science/hal-02172944}

Submitted on 4 Jul 2019

HAL is a multi-disciplinary open access archive for the deposit and dissemination of scientific research documents, whether they are published or not. The documents may come from teaching and research institutions in France or abroad, or from public or private research centers.
L'archive ouverte pluridisciplinaire HAL, est destinée au dépôt et à la diffusion de documents scientifiques de niveau recherche, publiés ou non, émanant des établissements d'enseignement et de recherche français ou étrangers, des laboratoires publics ou privés.

\section{(1)(1) $\$(0)$}

Distributed under a Creative Commons Attribution - NonCommercial - ShareAlikel 4.0 
3 Arnaud Moris ${ }^{1,2^{*}}$, Mathias Pereira ${ }^{1}$ and Lisa Chakrabarti ${ }^{3 *}$

4

5 Author affiliations:

$6{ }^{1}$ Sorbonne Université, INSERM, CNRS, Center for Immunology and Microbial Infections 7 CIMI-Paris, Paris, France

$8{ }^{2}$ Institute for Integrative Biology of the Cell (I2BC), CEA, CNRS, Universite Paris-Sud, 9 Université Paris-Saclay, Gif-sur-Yvette, France

$10{ }^{3}$ Virus and Immunity Unit, Control of Chronic Viral Infections (CIVIC) Group, Institut 11 Pasteur, Paris, France

12

13 A.M. and L.A.C. contributed equally to this work

14

15 * Correspondence:

16 Arnaud Moris (arnaud.moris@i2bc.paris-saclay.fr) and Lisa A. Chakrabarti 17 (chakra@pasteur.fr).

18

19 Arnaud Moris, Center for Immunology and Microbial Infections - CIMI-Paris, $91 \mathrm{Bd}$ de 20 l'Hôpital, 75013 Paris, France.

21

Lisa Chakrabarti, Virus and Immunity Unit, Control of Chronic Viral Infections (CIVIC) 23 group, Institut Pasteur, 28 rue du Dr Roux, 75724 Paris Cedex 15, France

24

25

26 


\section{Purpose of the review}

Rare patients naturally control HIV replication without antiretroviral therapy. Understanding the mechanisms implicated in natural HIV control will inform the development of immunotherapies against HIV. Elite controllers (EC) are known for developing efficient antiviral $\mathrm{T}$ cell responses, but recent findings suggest that antibody $(\mathrm{Ab})$ responses also play a significant role in HIV control. We review the key studies that uncovered a potent memory B cell response and highly functional anti-HIV Ab in EC, and explore the mechanisms that may account for the distinct properties of their humoral response.

\section{Recent findings}

EC maintain a large HIV-specific memory B cell pool that is sustained by efficient Tfh function. Neutralizing Ab rarely show high titers in controllers, but seem capable, at least in certain cases, of neutralizing contemporaneous viral strains. In addition, EC display a unique HIV-specific Ab profile in terms of isotype, antigen specificity, and glycosylation pattern, resulting in polyfunctional $\mathrm{Ab}$ effector functions that may promote infected cell lysis and prime effectors of the antiviral immune response.

\section{Summary}

Lessons from EC studies argue for the importance of integrating the many parameters defining a polyfunctional $\mathrm{Ab}$ response when evaluating candidate vaccines and

Key words: HIV control, memory B cells, neutralizing antibodies, ADCC, CD4+ T cell help. immunotherapeutic approaches directed at HIV. 


\section{INTRODUCTION}

Different groups of HIV-infected individuals naturally control HIV-1 (HIV) replication in the absence of combined antiretroviral therapy (cART): elite controllers (EC), who represent fewer than $1 \%$ of HIV-infected individuals and maintain very low to undetectable viremia (generally $<50$ copies HIV RNA/mL); viremic controllers (VC), who show partial viral control; and post-treatment controllers, who received cART but did not resume viral replication after treatment interruption [1,2]. Importantly, these groups of patients show a very low risk of progression to AIDS and usually maintain high CD4+ T cell counts [3]. In particular, EC show the strongest protection from disease and provide a unique opportunity to study immune responses involved in natural viral suppression [4].

It was long thought that cytotoxic CD8+ T cells (CTL) were the unique players involved in natural HIV control. Indeed, a fraction of EC exhibit potent CTL responses against HIVinfected cells, often associated with the expression of protective HLA alleles such as HLAB*57 and B*27 [2]. However, a growing body of evidence suggests that the humoral response, sustained by efficient CD4+ T cell help, is also a key player in HIV control. In this review, we highlight the recent works that uncovered a potent memory B cell response in EC, and that demonstrated the capacity of EC's sera to perform multiple effector functions possibly involved in HIV control. We also examine the mechanisms that could underlie the development and persistence of HIV-specific memory B cells in EC, including the preservation of CD4+ $\mathrm{T}$ follicular helper ( $\mathrm{Tfh}$ ) cell functions and the possibility of more efficient antigen presentation.

\section{Low Neutralizing antibody titers in EC}

The role of the humoral response was initially neglected in the HIV control research field, as several studies had shown that EC had low HIV neutralizing antibody (NAb) titers as compared to viremic individuals [5-9]. In addition, EC with the lowest levels of HIV replication, who remained undetectable even in high-sensitivity viral loads assays ( $\leq 1$ copy HIV RNA/mL), showed signs of low-intensity antibody responses, with fewer viral protein bands on HIV western blots, lower NAb titers, and lower cross-neutralization breadth [10]. Conversely, in viremic patients, the breadth of neutralization has been associated with higher viral loads [8,9,11-15], longer duration of viral exposure, and higher viral diversity [16]. In 
other words, in EC as in viremic patients, the availability of viral antigens seems to determine the magnitude of the antibody response, as well as its cross-neutralization capacity.

It should be noted, however, that EC show a marked heterogeneity, with some presenting broad cross-neutralization capacity while others show minimal or no neutralization [5-8,17]. A flurry of broadly neutralizing antibodies (bNAbs) capable of neutralizing diverse HIV strains were identified during the past decade. Of note, some of the original bNAbs were cloned from HIV-specific memory B cells isolated from EC, indicating that these rare patients have the capacity to produce potent anti-HIV antibodies $[17,18]$.

\section{Preserved memory B cell differentiation in EC}

Memory B cells, which are essential to sustain humoral immunity in the long-term, can be divided in 4 subpopulations: activated memory (AM), resting memory (RM), intermediate memory (IM) and tissue-like memory (TLM) B cells [19]. AM and TLM B cells, with the latter showing signs of anergy, are associated with higher levels of viremia [20,21]. In contrast, RM cells, which contribute to the long-term persistence of humoral responses, are decreased in progressor patients [19,22]. The picture that emerges is that of an abnormal immune activation that drives memory B cell exhaustion. cART decreases TLM and AM B cell proportions to near-normal levels in HIV-infected patients, but only restores the RM compartment in a subset of patients $[20,23,24]$. In EC, the proportions of the four memory B cell subsets are generally comparable to those observed in HIV-negative individuals [20,25]. However, the proportions of TLM B cells remain slightly elevated in EC, suggesting a degree of ongoing immune activation even in well-controlled HIV infection [20,25].

\section{Potent HIV-specific memory B cell responses in EC}

A key difference between EC and treated patients is that EC maintain a high frequency of HIV-specific memory B cells despite their low viral loads. These findings were obtained by measuring the frequency of circulating memory B cells capable of binding gp140 fluorescent probes [26] and by performing B cell ELISPOT assays [25]. Viremic patients who initiate cART show a marked decrease in the frequency of HIV-specific antibody-secreting cells (ASC), and patients treated in the long-term show low or undetectable HIV-specific ASC, consistent with the notion that viral replication is needed to constantly drive plasmablast differentiation in these patients [26-29]. In contrast, EC maintain a sizable memory B cell compartment despite limited antigenemia, suggesting that HIV-specific memory B cells are 
either longer lived in these rare patients or still generated or renewed due to antigen/Tfh access in lymphoid structures even with very low blood antigenemia.

This is not to say that EC are free of HIV replication. EC are more and more often treated with cART, which decreases immune activation, slightly increases CD4+ T cell counts, decreases ASC frequency, and further decreases the viral load in these already well-controlled patients [26,30,31]. Simian models suggest that limited viral replication persists in the germinal centers (GC) of lymphoid organs in untreated controller monkeys [32]. It is thus conceivable that the persistence of HIV-specific memory B cells in EC depends on residual viral replication in GC, at the very site of antibody response maturation. Interestingly, residual HIV replication appears to drive a persisting low-grade inflammation in some EC and to influence B cell fates. A specific inflammation profile, characterized by increased levels of CXCL13, sCD40L, IP10, RANTES, and TNF $\alpha$ in plasma, has been associated with the capacity to develop cross-neutralizing antibody responses in EC [33]. Further studies confirmed the association between CXCL13 levels and the breadth of the neutralizing $\mathrm{Ab}$ response in EC, emphasizing the role of this chemokine in Ab maturation [34].

\section{Association between memory B cells responses and HIV neutralization capacity}

Several studies analyzed whether the persistence of HIV-specific ASC, which include plasmablasts and memory B cells, might correlate with the titers of HIV-specific Ab and/or the breadth of neutralization. Most studies carried out on heterogeneous cohorts of EC failed to observe a correlation between cellular B cell responses and the magnitude or neutralization capacity of the $\mathrm{Ab}$ response [13,28,35]. Interestingly, by dividing $\mathrm{EC}$ into two subgroups expressing or not the protective HLA-B*57 allele, we observed among HLA-B*57+ EC that the frequency of HIV-specific ASC correlated positively with the capacity to neutralize various HIV strains, including Transmitter/Founder viruses [25]. As EC show an early spontaneous control of HIV replication [36], which is probably mediated by CTL antiviral effect in HLA-B*57+ EC [37], we propose that these CTL responses might favor the establishment of efficient memory B cell responses with cross-neutralization capacity, through the rapid control of the viral load, which could in turn avoid B cell exhaustion and preserve Tfh function. 
160 HIV constantly evades the selective pressure imposed by NAbs through mutational escape, so that at a given time the patient serum can neutralize previous but not contemporaneous viral strains isolated from the same patient [38]. Intriguingly, significant levels of autologous NAbs (that is, capable of neutralizing the contemporaneous viral strains) were detected in viremic controllers [39]. Recently, an in-depth longitudinal characterization of the humoral response in a HLA-B*57+ viremic controller revealed that this patient harbored autologous NAbs capable of neutralizing $88.5 \%$ of its circulating viral clones, suggesting that these NAbs contributed to HIV control [40]. Interestingly, NAbs in this patient could also cross-neutralize diverse heterologous HIV strains, suggesting that in some cases viral diversification can be efficiently matched by a diversification of the NAb response.

Preserved Tfh function may underlie the persistence of potent memory B cell responses in HIV controllers

Tfh cells, which reside within GC, provide help to B cells in the form of costimulatory signals and secretion of cytokines. Chronic HIV infection perturbs Tfh function, but paradoxically leads to an increase in Tfh numbers, which contributes to $\mathrm{GC}$ hyperplasia and lymphadenopathy [41]. Circulating Tfh (cTfh), defined as blood CXCR5+ CD4+ T cells, are thought to represent a form of memory $\mathrm{Tfh}$, that can reacquire $\mathrm{B}$ cell helper functions upon antigenic stimulation $[42,43]$. Interestingly, an increased proportion of cTfh subsets that express PD-1 [44] or PD-1 in the absence of CXCR3 [45,46] was associated with the development of a broad HIV-neutralizing antibody response, in adults and children. This suggests that $\mathrm{Tfh}$ that experience ongoing antigenic stimulation, as measured by PD-1 expression, are needed to sustain continued antibody maturation in the context of chronic HIV infection.

HIV control is associated with the persistence of highly functional CD4 effectors endowed with polyfunctional cytokine secretion and cytotoxic capacities [47,48]. The expression of HIV-specific T cell receptors of particularly high affinity accounts for the persistence of CD4 effector responses in EC [49,50]. Recent studies indicate that Tfh function is also highly efficient in EC. The frequency of HIV-specific cTfh, as measured by MHC-II tetramer labeling, remains higher in EC than in treated patients, and correlates with a higher production of HIV-specific antibodies in memory B cells/cTfh cocultures [51]. In addition, HIV-specific Tfh defined functionally as CXCR5+ CD4+ T cells with IL-21 secretion capacity are also 
preserved in EC, and show an association with the frequency of Env-specific memory B cells

194 [52]. Thus, key Tfh/B cell interactions are preserved in controlled HIV infection, which enables continued antibody affinity maturation (see Graff-Dubois et al. in this issue). These findings emphasize the need to induce robust Tfh function in vaccination and immune restauration strategies targeting HIV.

\section{A bias in Ab isotype and specificity in EC}

In addition to pathogen neutralization, Abs accomplish a variety of effector functions, with $\mathrm{Fc}$ receptors $(\mathrm{FcR})$ binding leading to cytokine secretion, antibody-dependent cellular phagocytosis (ADCP), antibody-dependent cell-mediated cytotoxicity (ADCC), and activation of the complement cascade. These different functions are strongly influenced by the immunoglobulin (Ig) isotype and the glycosylation status of the Ig Fc regions [53].

Although the IgG1 subclass dominates HIV-specific responses, the proportion of IgG isotypes varies depending on HLA type and clinical parameters [54-57]. A sequential study of Envspecific antibodies in controller and progressor patients showed that isotype profiles evolved over time, with a more prevalent Env-specific IgG2 response in controllers at early time points, while the IgG2 response developed more slowly in progressors [58]. In contrast, Envspecific IgG3 were present in both groups at early time points, but were progressively lost in progressors [58]. Isotype variations likely impact Fc-dependent functions, as for instance IgG1 and IgG3 generally bind $\mathrm{Fc}_{\gamma} \mathrm{Rs}$ with higher affinity than IgG2 and $\mathrm{IgG} 4$, with $\mathrm{IgG} 3$ being particularly efficient at mediating HIV internalization [59]. It is relevant that the loss of HIV-specific IgG3 occurs in synchrony with the loss of Fc-mediated functions that have been associated with viral control (see below) [60]. Accordingly, the sera from EC exhibiting strong polyfunctional antiviral activities are enriched in Abs of IgG1 and IgG3 subclasses [56]. Taken together, these studies suggest that the persistence of Env-specific IgG able to

Interestingly, HIV-specific IgA Abs were also detected at higher frequency in the sera of EC than in those of treated and viremic patients [61]. IgA responses in EC displayed broader antigen specificities and a particularly high avidity to the gp41 antigen [61]. Although serum IgA can clearly induce FcR-mediated phagocytosis of HIV [62], their phagocytic capacity 
trigger ADCC by monocytes and neutrophils, and IgG1 and IgA may actually cooperate rather than compete in the induction of FcR-mediated effector functions [63].

A role of Gag-specific antibodies in viral control has also been proposed. It is interesting that Gag-specific IgG2 [64,65] and IgG1 [66,67] have been associated with long-term nonprogression. Gag-specific IgG2 Abs seem particularly abundant in HLA-B*57-negative $\mathrm{EC}$, and may reflect a role for the humoral response in viral control when the CD8 response is not dominant $[57,68]$. However, the significance of anti-Gag responses in HIV infection remains unclear, as Gag proteins are not expressed at the cell or virion surface, and should thus not be accessible to Abs. Gag-specific Abs may still be able to capture secreted Gag, broken virions, or infected cell fragments, which may in turn facilitate the uptake and presentation of Gag antigens to Gag-specific $\mathrm{CD} 4+$ and $\mathrm{CD} 8+\mathrm{T}$ cells, which are immunodominant in EC and thought to play a key role in suppressing HIV replication $[2,69]$.

\section{A more potent ADCC function in EC?}

HIV-specific ADCC, primarily mediated by NK cells, develops rapidly in the course of HIV infection and exerts an immune selective pressure on the virus, suggesting that it contributes to decrease the pool of infected cells during the early stages of infection [70-72]. Whether ADCC participates in viral control in EC during the chronic stage of infection remains debated [73]. Several studies did not detect an improved capacity of EC sera to mediate $\mathrm{ADCC}[56,74,75]$. In contrast, Abs mediating ADCC were found to be increased in other EC cohorts [5,76], with one study reporting a predominant ADCC response in HLA-B*57-

These contrasting findings reflect the heterogeneity of ADCC responses in EC, but also the variable definitions of controller status in the different EC cohorts. The choice of the control group may also influence study outcome, as for instance viremic patients at an advanced stage of infection tend to show lower HIV-specific Ab levels in the circulation. There is clear evidence that the level of Env-specific Ab binding at the surface of infected cells is a correlate of ADCC activity [75]. Indeed, NAbs with an intrinsically higher capacity to bind the surface of infected CD4+ $\mathrm{T}$ cells show more efficient ADCC activity against these cells [78]. Competition between different types of antibodies may also influence ADCC function [79]. IgG3 are likely important in NK-mediated ADCC, as they have a particularly high affinity for 
261 ADCC activity also depends on the strength of NK cell activation. Specific associations between certain NK cell receptors allotypes and their MHC-I molecule ligands, such as KIR3DL1 and HLA-B*57, influence disease progression and are associated with lower viremia [81]. Nonetheless, NK cells from EC and progressors have so far shown similar capacities to perform ADCC [56,74,82]. Therefore, the involvement of NK receptor allotypes in viral control may rely on the direct recognition of infected cells by NK cells, through NK receptor engagement rather than $\mathrm{ADCC}$.

\section{Polyfunctional Ab-effector functions in EC}

Given the diversity of $\mathrm{Ab}$ effector functions, it seems unlikely that a single attribute of the $\mathrm{Ab}$ response may account for the unique capacity of EC to control HIV infection. To tackle this issue, Ackerman and Alter developed a systematic approach to study in a single sample an array of functions, including ADCC, NK activation, complement deposition (ADCD), ADCP, and $\mathrm{Ab}$ attributes, such as glycosylation status and FcR binding capacity $[56,66]$. This "systems serology" approach did not show a superior capacity of EC's sera to perform any of the above-mentioned functions. Rather, it revealed that the different Ab functions, except for ADCP, strongly correlated with one another in EC. In particular, ADCD correlated with all other functions, suggesting that $\mathrm{EC}$ developed a more coordinated $\mathrm{Ab}$ response than other patient groups [56]. EC exhibiting these polyfunctional antiviral activities had sera enriched in IgG1 and IgG3 HIV-specific Abs, pointing out to the importance of isotype subclasses in determining the overall quality of the antibody response [56].

$\mathrm{Ab}$ effector functions depend on binding to FcRs and to initiators of the complement cascade, with these steps being tightly regulated by the glycolysation of the Ig Fc region $[83,84]$. In humans, the IgG Fc-domain harbors a single glycosylation site that can accommodate up to 30 documented different glycan structures. In EC, a shift of the glycosylation profile toward agalactosylated glycoforms was observed in the total Ab pool [85]. In particular, HIV-specific Abs exhibited a high frequency of agalactosylated, afucosylated, and asialylated glycans [85]. These particular Ab glycoforms have been associated with enhanced FcR-mediated antiviral functions, and may thus account for the quality of $\mathrm{Ab}$ effector functions in EC. Interestingly, in EC, the presence of the particular glycoform G1S1F was strongly associated with emergence of HIV-specific IgG3, suggesting that coordinated changes underlie the development of polyfunctional Ab responses [66]. Overall, systems serology studies are 
starting to shed light on the many interdependent parameters involved in defining the quality

295 of antiviral Ab responses.

297 In addition to mediating direct antiviral activities, FcR-dependent Ab functions such as ADCP 298 and complement deposition also enhance innate and adaptive immunity, by inducing cytokine 299 secretion and promoting viral antigen presentation. For instance, injection of bNAbs in SHIV 300 infected macaques and HIV-infected patients was shown to enhance $\mathrm{T}$ cell immunity and 301 increase the neutralization breadth of endogenous Abs [86,87]. CD8 $+\mathrm{T}$ cell responses in 302 particular were shown to contribute to durable viral control in bNAb-treated animals [88]. The underlying mechanisms are not elucidated yet, but may depend on increased formation of 304 immune complexes and/or complement opsonisation (see Naranjo-Gomez \& Pelegrin in this 305 issue). Viral immune complexes were shown to promote antigen capture and dendritic cell 306 (DC) maturation [89,90]. HIV immune complexes could also induce an antiviral state by 307 triggering the production of type I interferon by plasmacytoid DC [91]. The enhancing effect 308 of NAbs on adaptive antiviral immunity has yet to be fully investigated in EC, but it is interesting to note that DC from EC are more efficient at capturing HIV particles [92].

\section{CONCLUSION}

312 Increasing evidence suggest that humoral responses play an important role in natural HIV 313 control. EC maintain a large HIV-specific memory B cell pool that is sustained by efficient 314 Tfh function. NAb rarely show high titers in controllers, but seem capable, at least in certain 315 cases, of neutralizing contemporaneous viral strains, and thus of directly contributing to viral 316 control. In addition, EC display a unique HIV-specific Ab profile in terms of isotype and glycosylation pattern, resulting in polyfunctional $\mathrm{Ab}$ effector functions that may promote

318 infected cell lysis and prime multiple effectors of the antiviral immune response. Lessons 319 from EC studies argue for the importance of integrating the many parameters defining a 320 polyfunctional $\mathrm{Ab}$ response when evaluating candidate vaccines and immunotherapeutic 321 approaches directed at HIV.

\section{KEY POINTS}

324 - Persistence of a large HIV-specific memory B cell pool in EC

325 - Efficient Tfh help sustains memory B cells in EC

326 - Efficient neutralization of contemporaneous autologous viral strains in some EC and VC

327 - Increased frequency of Gag-specific antibodies in EC 
- Persistence of Env-specific IgG3, which mediate NK-dependent ADCC in EC

- Shift of the HIV-specific IgG glycosylation profile in EC

- Polyfunctional Ab effector responses in EC

- Converging evidence that the humoral response plays a key role in natural HIV control

ACKNOWLEDGMENTS

We thank all the participants and investigators of the ANRS CO21 CODEX cohort. We apologize to the authors whose valuable work could not be discussed due to length constraints.

\section{FINANCIAL SUPPORT and SPONSORSHIP}

We thank ANRS, Sidaction, and ANR for financial support.

\section{CONFLICTS OF INTEREST}

343 The authors declare no conflict of interest.

\section{REFERENCES}

1. Lambotte O, Delfraissy J-F: HIV controllers: a homogeneous group of HIV-1 infected patients with a spontaneous control of viral replication. Clinical Infectious Diseases 2005, 41:1053-1056.

2. Saez-Cirion A, Manel N: Immune Responses to Retroviruses. Annu Rev Immunol 2018, 36:193-220.

3. Grabar S, Selinger-Leneman H, Abgrall S, Pialoux G, Weiss L, Costagliola D: Prevalence and comparative characteristics of long-term nonprogressors and HIV controller patients in the French Hospital Database on HIV. AIDS 2009, 23:1163-1169.

4. Walker BD, Yu XG: Unravelling the mechanisms of durable control of HIV-1. Nat Rev Immunol 2013, 13:487-498.

5. Lambotte O, Ferrari G, Moog C, Yates NL, Liao H-X, Parks RJ, Hicks CB, Owzar K, Tomaras GD, Montefiori DC, et al.: Heterogeneous neutralizing antibody and antibody-dependent cell cytotoxicity responses in HIV-1 elite controllers. AIDS (London, England) 2009, 23:897-906.

6. Pereyra F, Addo MM, Kaufmann DE, Liu Y, Miura T, Rathod A, Baker B, Trocha A, Rosenberg R, Mackey E, et al.: Genetic and immunologic heterogeneity among persons who control HIV infection in the absence of therapy. The Journal of infectious diseases 2008, 197:563-571.

7. Bailey JR, Lassen KG, Yang HC, Quinn TC, Ray SC, Blankson JN, Siliciano RF: Neutralizing antibodies do not mediate suppression of human immunodeficiency virus type 1 in elite suppressors or selection of plasma virus variants in patients on highly active antiretroviral therapy. $J$ Virol 2006, 80:4758-4770.

8. Sajadi MM, Guan Y, DeVico AL, Seaman MS, Hossain M, Lewis GK, Redfield RR: Correlation between circulating HIV-1 RNA and broad HIV-1 neutralizing antibody activity. J Acquir Immune Defic Syndr 2011, 57:9-15.

9. Doria-Rose NA, Klein RM, Daniels MG, O'Dell S, Nason M, Lapedes A, Bhattacharya T, Migueles SA, Wyatt RT, Korber BT, et al.: Breadth of human immunodeficiency virus-specific neutralizing activity in sera: clustering analysis and association with clinical variables. J Virol 2010, 84:1631-1636. 
10. Pereyra F, Palmer S, Miura T, Block BL, Wiegand A, Rothchild AC, Baker B, Rosenberg R, Cutrell E, Seaman MS, et al.: Persistent low-level viremia in HIV-1 elite controllers and relationship to immunologic parameters. The Journal of infectious diseases 2009, 200:984-990.

11. Piantadosi A, Panteleeff D, Blish CA, Baeten JM, Jaoko W, McClelland RS, Overbaugh J: Breadth of neutralizing antibody response to human immunodeficiency virus type 1 is affected by factors early in infection but does not influence disease progression. $J$ Virol 2009, 83:10269-10274.

12. Deeks SG, Schweighardt B, Wrin T, Galovich J, Hoh R, Sinclair E, Hunt P, McCune JM, Martin JN, Petropoulos CJ, et al.: Neutralizing antibody responses against autologous and heterologous viruses in acute versus chronic human immunodeficiency virus (HIV) infection: evidence for a constraint on the ability of HIV to completely evade neutralizing antibody responses. $J$ Virol 2006, 80:6155-6164.

13. Doria-Rose NA, Klein RM, Manion MM, O'Dell S, Phogat A, Chakrabarti B, Hallahan CW, Migueles SA, Wrammert J, Ahmed R, et al.: Frequency and phenotype of human immunodeficiency virus envelope-specific $B$ cells from patients with broadly cross-neutralizing antibodies. J Virol 2009, 83:188-199.

14. Sather DN, Armann J, Ching LK, Mavrantoni A, Sellhorn G, Caldwell Z, Yu X, Wood B, Self S, Kalams S, et al.: Factors associated with the development of cross-reactive neutralizing antibodies during human immunodeficiency virus type 1 infection. J Virol 2009, 83:757-769.

15. Rodriguez SK, Sarr AD, MacNeil A, Thakore-Meloni S, Gueye-Ndiaye A, Traore I, Dia MC, Mboup S, Kanki PJ: Comparison of heterologous neutralizing antibody responses of human immunodeficiency virus type 1 (HIV1)- and HIV-2-infected Senegalese patients: distinct patterns of breadth and magnitude distinguish HIV-1 and HIV-2 infections. $J$ Virol 2007, 81:5331-5338.

16. Rusert P, Kouyos RD, Kadelka C, Ebner H, Schanz M, Huber M, Braun DL, Hoze N, Scherrer A, Magnus C, et al.: Determinants of HIV-1 broadly neutralizing antibody induction. Nat Med 2016, 22:1260-1267.

17. Scheid JF, Mouquet H, Feldhahn N, Seaman MS, Velinzon K, Pietzsch J, Ott RG, Anthony RM, Zebroski H, Hurley A, et al.: Broad diversity of neutralizing antibodies isolated from memory B cells in HIV-infected individuals. Nature 2009, 458:636-640.

18. Scheid JF, Mouquet H, Ueberheide B, Diskin R, Klein F, Oliveira TY, Pietzsch J, Fenyo D, Abadir A, Velinzon K, et al.: Sequence and structural convergence of broad and potent HIV antibodies that mimic CD4 binding. Science 2011, 333:1633-1637.

19. Moir S, Fauci AS: B-cell responses to HIV infection. Immunol Rev 2017, 275:33-48.

20. Pensieroso S, Galli L, Nozza S, Ruffin N, Castagna A, Tambussi G, Hejdeman B, Misciagna D, Riva A, Malnati M, et al.: B-cell subset alterations and correlated factors in HIV-1 infection. AIDS (London, England) 2013, 27:12091217.

21. Kardava L, Moir S, Shah N, Wang W, Wilson R, Buckner CM, Santich BH, Kim LJY, Spurlin EE, Nelson AK, et al.: Abnormal B cell memory subsets dominate HIV-specific responses in infected individuals. The Journal of clinical investigation 2014, 124:3252-3262.

22. Good KL, Avery DT, Tangye SG: Resting Human Memory B Cells Are Intrinsically Programmed for Enhanced Survival and Responsiveness to Diverse Stimuli Compared to Naive B Cells. The Journal of Immunology 2009, 182:890-901.

23. Moir S, Ho J, Malaspina A, Wang W, DiPoto AC, O'Shea MA, Roby G, Kottilil S, Arthos J, Proschan MA, et al.: Evidence for HIV-associated B cell exhaustion in a dysfunctional memory B cell compartment in HIVinfected viremic individuals. The Journal of experimental medicine 2008, 205:1797-1805.

24. Moir S, Buckner CM, Ho J, Wang W, Chen J, Waldner AJ, Posada JG, Kardava L, Shea MaO, Kottilil S, et al.: B cells in early and chronic HIV infection : evidence for preservation of immune function associated with early initiation of antiretroviral therapy. Blood 2010, 116:5571-5579. 
25. Rouers A, Klingler J, Su B, Samri A, Laumond G, Even S, Avettand-Fenoel V, Richetta C, Paul N, Boufassa F, et al.: HIV-Specific B Cell Frequency Correlates with Neutralization Breadth in Patients Naturally Controlling HIV-Infection. EBioMedicine 2017, 21:158-169.

** The analysis of ASC in a large cohort of EC revealed the persistence of HIV-specific memory B cells in this group. A positive correlation between HIV-specific memory B cell frequency and neutralization breadth was detected only in EC carrying the protective HLAB*57 allele.

26. Buckner CM, Kardava L, Zhang X, Gittens K, Justement JS, Kovacs C, McDermott AB, Li Y, Sajadi MM, Chun T-W, et al.: Maintenance of HIV-Specific Memory B-Cell Responses in Elite Controllers Despite Low Viral Burden. Journal of Infectious Diseases 2016:jiw163.

** The detection of gp120-binding B cells in the circulation revealed that HIV-specific memory B cells persisted at a high frequency in EC, while they were lost in treated patients.

27. Morris L, Binley JM, Clas BA, Bonhoeffer S, Astill TP, Kost R, Hurley A, Cao Y, Markowitz M, Ho DD, et al.: HIV-1 antigen-specific and -nonspecific $B$ cell responses are sensitive to combination antiretroviral therapy. $J$ Exp Med 1998, 188:233-245.

28. Bussmann BM, Reiche S, Bieniek B, Krznaric I, Ackermann F, Jassoy C: Loss of HIV-specific memory B-cells as a potential mechanism for the dysfunction of the humoral immune response against HIV. Virology 2010, 397:713.

29. Fondere J-M, Huguet M-F, Macura-Biegun A, Baillat V, Ohayon V, Reynes J, Vendrell J-P: Detection and enumeration of circulating HIV-1-specific memory B cells in HIV-1-infected patients. Journal of acquired immune deficiency syndromes (1999) 2004, 35:114-119.

30. Hatano H, Yukl SA, Ferre AL, Graf EH, Somsouk M, Sinclair E, Abdel-Mohsen M, Liegler T, Harvill K, Hoh R, et al.: Prospective antiretroviral treatment of asymptomatic, HIV-1 infected controllers. PLoS Pathog 2013, 9:e1003691.

31. Boufassa F, Lechenadec J, Meyer L, Costagliola D, Hunt PW, Pereyra F, Deeks S, Pancino G, Taulera O, Lichterfeld M, et al.: Blunted response to combination antiretroviral therapy in HIV elite controllers: an international HIV controller collaboration. PLoS One 2014, 9:e85516.

32. Fukazawa Y, Lum R, Okoye AA, Park H, Matsuda K, Bae JY, Hagen SI, Shoemaker R, Deleage C, Lucero C, et al.: B cell follicle sanctuary permits persistent productive simian immunodeficiency virus infection in elite controllers. Nat Med 2015, 21:132-139.

33. Dugast AS, Arnold K, Lofano G, Moore S, Hoffner M, Simek M, Poignard P, Seaman M, Suscovich TJ, Pereyra F, et al.: Virus-driven Inflammation Is Associated With the Development of bNAbs in Spontaneous Controllers of HIV. Clin Infect Dis 2017, 64:1098-1104.

* This study identified a specific inflammation profile associated with the development of neutralization breadth in EC.

34. Mabuka JM, Dugast AS, Muema DM, Reddy T, Ramlakhan Y, Euler Z, Ismail N, Moodley A, Dong KL, Morris L, et al.: Plasma CXCL13 but Not B Cell Frequencies in Acute HIV Infection Predicts Emergence of CrossNeutralizing Antibodies. Frontiers in Immunology 2017, 8.

35. Guan Y, Sajadi MM, Kamin-Lewis R, Fouts TR, Dimitrov A, Zhang Z, Redfield RR, DeVico AL, Gallo RC, Lewis GK: Discordant memory $B$ cell and circulating anti-Env antibody responses in HIV-1 infection. Proc Natl Acad Sci U S A 2009, 106:3952-3957. 
36. Goujard C, Chaix ML, Lambotte O, Deveau C, Sinet M, Guergnon J, Courgnaud V, Rouzioux C, Delfraissy JF, Venet A, et al.: Spontaneous control of viral replication during primary HIV infection: when is "HIV controller" status established? Clin Infect Dis 2009, 49:982-986.

37. Sáez-Cirión A, Lacabaratz C, Lambotte O, Versmisse P, Urrutia A, Boufassa F, Barré-Sinoussi F, Delfraissy J-F, Sinet M, Pancino G, et al.: HIV controllers exhibit potent CD8 T cell capacity to suppress HIV infection ex vivo and peculiar cytotoxic T lymphocyte activation phenotype. Proceedings of the National Academy of Sciences of the United States of America 2007, 104:6776-6781.

38. Richman DD, Wrin T, Little SJ, Petropoulos CJ: Rapid evolution of the neutralizing antibody response to HIV type 1 infection. Proc Natl Acad Sci U S A 2003, 100:4144-4149.

39. Mahalanabis M, Jayaraman P, Miura T, Pereyra F, Chester EM, Richardson B, Walker B, Haigwood NL: Continuous viral escape and selection by autologous neutralizing antibodies in drug-naive human immunodeficiency virus controllers. $J$ Virol 2009, 83:662-672.

40. Freund NT, Wang H, Scharf L, Nogueira L, Horwitz JA, Bar-On Y, Golijanin J, Sievers SA, Sok D, Cai H, et al.: Coexistence of potent HIV-1 broadly neutralizing antibodies and antibody-sensitive viruses in a viremic controller. Sci Transl Med 2017, 9.

** This in-depth longitudinal characterization of the humoral response in a HLA-B*57+ viremic controller suggests that NAbs contribute to HIV control.

41. Havenar-Daughton C, Lee JH, Crotty S: Tfh cells and HIV bnAbs, an immunodominance model of the HIV neutralizing antibody generation problem. Immunol Rev 2017, 275:49-61.

42. Morita R, Schmitt N, Bentebibel SE, Ranganathan R, Bourdery L, Zurawski G, Foucat E, Dullaers M, Oh S, Sabzghabaei $\mathrm{N}$, et al.: Human blood CXCR5(+)CD4(+) $\mathrm{T}$ cells are counterparts of $\mathrm{T}$ follicular cells and contain specific subsets that differentially support antibody secretion. Immunity 2011, 34:108-121.

43. Schultz BT, Teigler JE, Pissani F, Oster AF, Kranias G, Alter G, Marovich M, Eller MA, Dittmer U, Robb ML, et al.: Circulating HIV-Specific Interleukin-21(+)CD4(+) T Cells Represent Peripheral Tfh Cells with AntigenDependent Helper Functions. Immunity 2016, 44:167-178.

44. Cohen K, Altfeld M, Alter G, Stamatatos L: Early preservation of CXCR5+ PD-1+ helper T cells and B cell activation predict the breadth of neutralizing antibody responses in chronic HIV-1 infection. J Virol 2014, 88:13310-13321.

45. Locci M, Havenar-Daughton C, Landais E, Wu J, Kroenke MA, Arlehamn CL, Su LF, Cubas R, Davis MM, Sette A, et al.: Human circulating PD-1+CXCR3-CXCR5+ memory Tfh cells are highly functional and correlate with broadly neutralizing HIV antibody responses. Immunity 2013, 39:758-769.

46. Roider J, Maehara T, Ngoepe A, Ramsuran D, Muenchhoff M, Adland E, Aicher T, Kazer SW, Jooste P, Karim F, et al.: High-Frequency, Functional HIV-Specific T-Follicular Helper and Regulatory Cells Are Present Within Germinal Centers in Children but Not Adults. Front Immunol 2018, 9:1975.

47. Chakrabarti LA, Simon V: Immune mechanisms of HIV control. Curr Opin Immunol 2010, 22:488-496.

48. Soghoian DZ, Jessen H, Flanders M, Sierra-Davidson K, Cutler S, Pertel T, Ranasinghe S, Lindqvist M, Davis I, Lane K, et al.: HIV-specific cytolytic CD4 T cell responses during acute HIV infection predict disease outcome. Sci Transl Med 2012, 4:123ra125.

49. Benati D, Galperin M, Lambotte O, Gras S, Lim A, Mukhopadhyay M, Nouel A, Campbell KA, Lemercier B, Claireaux M, et al.: Public T cell receptors confer high-avidity CD4 responses to HIV controllers. J Clin Invest 2016, 126:2093-2108.

50. Galperin M, Farenc C, Mukhopadhyay M, Jayasinghe D, Decroos A, Benati D, Tan LL, Ciacchi L, Reid HH, Rossjohn J, et al.: CD4(+) T cell-mediated HLA class II cross-restriction in HIV controllers. Sci Immunol 2018, 3. 
51. Claireaux M, Galperin M, Benati D, Nouel A, Mukhopadhyay M, Klingler J, de Truchis P, Zucman D, Hendou S, Boufassa F, et al.: A High Frequency of HIV-Specific Circulating Follicular Helper T Cells Is Associated with Preserved Memory B Cell Responses in HIV Controllers. MBio 2018, 9.

** This article reports a high frequency of HIV-specific circulating Tfh in EC, which correlates with the induction of HIV-specific antibodies in functional assays.

52. Buranapraditkun S, Pissani F, Teigler JE, Schultz BT, Alter G, Marovich M, Robb ML, Eller MA, Martin J, Deeks S, et al.: Preservation of Peripheral T Follicular Helper Cell Function in HIV Controllers. J Virol 2017, 91.

53. Bruhns P, Jonsson F: Mouse and human FcR effector functions. Immunol Rev 2015, 268:25-51.

54. Binley JM, Lybarger EA, Crooks ET, Seaman MS, Gray E, Davis KL, Decker JM, Wycuff D, Harris L, Hawkins N, et al.: Profiling the specificity of neutralizing antibodies in a large panel of plasmas from patients chronically infected with human immunodeficiency virus type 1 subtypes B and C. $J$ Virol 2008, 82:11651-11668.

55. Banerjee K, Klasse PJ, Sanders RW, Pereyra F, Michael E, Lu M, Walker BD, Moore JP: IgG subclass profiles in infected HIV type 1 controllers and chronic progressors and in uninfected recipients of Env vaccines. AIDS research and human retroviruses 2010, 26:445-458.

56. Ackerman ME, Mikhailova A, Brown EP, Dowell KG, Walker BD, Bailey-Kellogg C, Suscovich TJ, Alter G: Polyfunctional HIV-Specific Antibody Responses Are Associated with Spontaneous HIV Control. PLOS Pathogens 2016, 12:e1005315.

57. French Ma, Center RJ, Wilson KM, Fleyfel I, Fernandez S, Schorcht A, Stratov I, Kramski M, Kent SJ, Kelleher AD: Isotype-switched immunoglobulin G antibodies to HIV Gag proteins may provide alternative or additional immune responses to 'protective' human leukocyte antigen-B alleles in HIV controllers. AIDS (London, England) 2013, 27:519-528.

58. Sadanand S, Das J, Chung AW, Schoen MK, Lane S, Suscovich TJ, Streeck H, Smith DM, Little SJ, Lauffenburger DA, et al.: Temporal variation in HIV-specific IgG subclass antibodies during acute infection differentiates spontaneous controllers from chronic progressors. Aids 2018, 32:443-450.

* This study highlights that temporal variations of Env-specific IgG subclasses during acute HIV infection are predictive of HIV control. In particular, Env-specific IgG3 responses persist longer in EC.

59. Tay MZ, Liu P, Williams LD, McRaven MD, Sawant S, Gurley TC, Xu TT, Dennison SM, Liao HX, Chenine AL, et al.: Antibody-Mediated Internalization of Infectious HIV-1 Virions Differs among Antibody Isotypes and Subclasses. PLoS Pathog 2016, 12:e1005817.

60. Dugast AS, Stamatatos L, Tonelli A, Suscovich TJ, Licht AF, Mikell I, Ackerman ME, Streeck H, Klasse PJ, Moore JP, et al.: Independent evolution of Fc- and Fab-mediated HIV-1-specific antiviral antibody activity following acute infection. Eur J Immunol 2014, 44:2925-2937.

61. Nabi R, Moldoveanu Z, Wei Q, Golub ET, Durkin HG, Greenblatt RM, Herold BC, Nowicki MJ, Kassaye S, Cho MW, et al.: Differences in serum IgA responses to HIV-1 gp41 in elite controllers compared to viral suppressors on highly active antiretroviral therapy. PLoS One 2017, 12:e180245.

* This study suggests that HIV-specific IgA responses are more prevalent and affinity maturation of anti-gp41 IgA antibodies occurs to a greater extent in EC than in patients on cART.

62. Wills S, Hwang KK, Liu P, Dennison SM, Tay MZ, Shen X, Pollara J, Lucas JT, Parks R, Rerks-Ngarm S, et al.: HIV-1Specific IgA Monoclonal Antibodies from an HIV-1 Vaccinee Mediate Galactosylceramide Blocking and Phagocytosis. J Virol 2018, 92. 
63. Duchemin M, Khamassi M, Xu L, Tudor D, Bomsel M: IgA Targeting Human Immunodeficiency Virus-1 Envelope gp41 Triggers Antibody-Dependent Cellular Cytotoxicity Cross-Clade and Cooperates with gp41-Specific IgG to Increase Cell Lysis. Front Immunol 2018, 9:244.

64. Martinez V, Costagliola D, Bonduelle O, N'Go N, Schnuriger A, Théodorou I, Clauvel JP, Sicard D, Agut H, Debré P, et al.: Combinaison of HIV-1- specific CD4 Th1 cell reponses and IgG2 antibodies is the best predictor for persistence of long-term non progression. J Infect Dis;. Journal of infectious disease 2005, 191:191:2053-2063.

** This system serology study revealed the multifaceted contributions of polyclonal patterns may be predictive of viral control.

67. Tjiam MC, Sariputra L, Armitage JD, Taylor JP, Kelleher AD, Tan DB, Lee S, Fernandez S, French MA: Control of early HIV-1 infection associates with plasmacytoid dendritic cell-reactive opsonophagocytic IgG antibodies to HIV-1 p24. AIDS 2016, 30:2757-2765.

68. Tjiam MC, Morshidi MA, Sariputra L, Martin JN, Deeks SG, Tan DBA, Lee S, Fernandez S, French MA: Association of HIV-1 Gag-Specific IgG Antibodies With Natural Control of HIV-1 Infection in Individuals Not Carrying HLA-B*57: 01 Is Only Observed in Viremic Controllers. J Acquir Immune Defic Syndr 2017, 76:e90-e92.

69. Ranasinghe S, Flanders M, Cutler S, Soghoian DZ, Ghebremichael M, Davis I, Lindqvist M, Pereyra F, Walker BD, Heckerman D, et al.: HIV-specific CD4 T cell responses to different viral proteins have discordant associations with viral load and clinical outcome. $J$ Virol 2012, 86:277-283.

70. Chung AW, Navis M, Isitman G, Centre R, Finlayson R, Bloch M, Gelgor L, Kelleher A, Kent SJ, Stratov I: Activation of NK cells by ADCC responses during early HIV infection. Viral Immunol 2011, 24:171-175.

71. Chung AW, Isitman G, Navis M, Kramski M, Center RJ, Kent SJ, Stratov I: Immune escape from HIV-specific antibody-dependent cellular cytotoxicity (ADCC) pressure. Proc Natl Acad Sci U S A 2011, 108:7505-7510.

72. Chen X, Lin M, Qian S, Zhang Z, Fu Y, Xu J, Han X, Ding H, Dong T, Shang H, et al.: The Early Antibody-Dependent Cell-Mediated Cytotoxicity Response Is Associated With Lower Viral Set Point in Individuals With Primary HIV Infection. Front Immunol 2018, 9:2322.

73. Forthal DN, Finzi A: Antibody-dependent cellular cytotoxicity in HIV infection. AIDS 2018, 32:2439-2451.

74. Johansson SE, Rollman E, Chung AW, Center RJ, Hejdeman B, Stratov I, Hinkula J, Wahren B, Karre K, Kent SJ, et al.: NK cell function and antibodies mediating ADCC in HIV-1-infected viremic and controller patients. Viral Immunol 2011, 24:359-368.

75. Smalls-Mantey A, Doria-Rose N, Klein R, Patamawenu A, Migueles SA, Ko SY, Hallahan CW, Wong H, Liu B, You L, et al: Antibody-dependent cellular cytotoxicity against primary HIV-infected CD4+ $\mathrm{T}$ cells is directly associated with the magnitude of surface IgG binding. $J$ Virol 2012, 86:8672-8680.

76. Madhavi V, Wines BD, Amin J, Emery S, Group ES, Lopez E, Kelleher A, Sydney LSG, Center RJ, Hogarth PM, et al.: HIV-1 Env- and Vpu-Specific Antibody-Dependent Cellular Cytotoxicity Responses Associated with Elite Control of HIV. J Virol 2017, 91.

77. Lambotte O, Pollara J, Boufassa F, Moog C, Venet A, Haynes BF, Delfraissy JF, Saez-Cirion A, Ferrari G: High antibody-dependent cellular cytotoxicity responses are correlated with strong CD8 $\mathbf{T}$ cell viral suppressive activity but not with B57 status in HIV-1 elite controllers. PLoS One 2013, 8:e74855. 
78. Bruel T, Guivel-Benhassine F, Lorin V, Lortat-Jacob H, Baleux F, Bourdic K, Noel N, Lambotte O, Mouquet H, Schwartz O: Lack of ADCC Breadth of Human Nonneutralizing Anti-HIV-1 Antibodies. J Virol 2017, 91.

79. Tomaras GD, Ferrari G, Shen X, Alam SM, Liao HX, Pollara J, Bonsignori M, Moody MA, Fong Y, Chen X, et al.: Vaccine-induced plasma IgA specific for the C1 region of the HIV-1 envelope blocks binding and effector function of IgG. Proc Natl Acad Sci U S A 2013, 110:9019-9024.

80. Gillis C, Gouel-Cheron A, Jonsson F, Bruhns P: Contribution of Human FcgammaRs to Disease with Evidence from Human Polymorphisms and Transgenic Animal Studies. Front Immunol 2014, 5:254.

81. Martin MP, Naranbhai V, Shea PR, Qi Y, Ramsuran V, Vince N, Gao X, Thomas R, Brumme ZL, Carlson JM, et al.: Killer cell immunoglobulin-like receptor 3DL1 variation modifies HLA-B*57 protection against HIV-1. $J$ Clin Invest 2018, 128:1903-1912.

82. Isitman G, Lisovsky I, Tremblay-McLean A, Kovacs C, Harris M, Routy JP, Bruneau J, Wainberg MA, Tremblay C, Bernard NF: Antibody-Dependent Cellular Cytotoxicity Activity of Effector Cells from HIV-Infected Elite and Viral Controllers. AIDS Res Hum Retroviruses 2016, 32:1079-1088.

83. Alter G, Ottenhoff THM, Joosten SA: Antibody glycosylation in inflammation, disease and vaccination. Semin Immunol 2018, 39:102-110.

84. Lofano G, Gorman MJ, Yousif AS, Yu WH, Fox JM, Dugast AS, Ackerman ME, Suscovich TJ, Weiner J, Barouch D, et al.: Antigen-specific antibody $F c$ glycosylation enhances humoral immunity via the recruitment of complement. Sci Immunol 2018, 3.

85. Ackerman ME, Crispin M, Yu X, Baruah K, Boesch AW, Harvey DJ, Dugast AS, Heizen EL, Ercan A, Choi I, et al.: Natural variation in Fc glycosylation of HIV-specific antibodies impacts antiviral activity. J Clin Invest 2013, 123:2183-2192.

86. Barouch DH, Whitney JB, Moldt B, Klein F, Oliveira TY, Liu J, Stephenson KE, Chang HW, Shekhar K, Gupta S, et al.: Therapeutic efficacy of potent neutralizing HIV-1-specific monoclonal antibodies in SHIV-infected rhesus monkeys. Nature 2013, 503:224-228.

87. Schoofs T, Klein F, Braunschweig M, Kreider EF, Feldmann A, Nogueira L, Oliveira T, Lorenzi JC, Parrish EH, Learn GH, et al.: HIV-1 therapy with monoclonal antibody 3BNC117 elicits host immune responses against HIV-1. Science 2016, 352:997-1001.

88. Nishimura Y, Gautam R, Chun TW, Sadjadpour R, Foulds KE, Shingai M, Klein F, Gazumyan A, Golijanin J, Donaldson M, et al.: Early antibody therapy can induce long-lasting immunity to SHIV. Nature 2017, 543:559-563.

** This study shows that passive immunotherapy during acute SHIV infection facilitates the emergence of potent cytotoxic CD8 $+\mathrm{T}$ cell responses that contribute to a durable suppression of virus replication.

89. Su B, Xu K, Lederle A, Peressin M, Biedma ME, Laumond G, Schmidt S, Decoville T, Proust A, Lambotin M, et al.: Neutralizing antibodies inhibit HIV-1 transfer from primary dendritic cells to autologous CD4 T lymphocytes. Blood 2012, 120:3708-3717.

90. Posch W, Steger M, Knackmuss U, Blatzer M, Baldauf HM, Doppler W, White TE, Hortnagl P, Diaz-Griffero F, LassFlorl C, et al.: Complement-Opsonized HIV-1 Overcomes Restriction in Dendritic Cells. PLoS Pathog 2015, 11:e1005005.

91. Veenhuis RT, Freeman ZT, Korleski J, Cohen LK, Massaccesi G, Tomasi A, Boesch AW, Ackerman ME, Margolick JB, Blankson JN, et al.: HIV-antibody complexes enhance production of type $I$ interferon by plasmacytoid dendritic cells. $J$ Clin Invest 2017, 127:4352-4364.

92. Hamimi C, David A, Versmisse P, Weiss L, Bruel T, Zucman D, Appay V, Moris A, Ungeheuer MN, Lascoux-Combe C, et al.: Dendritic Cells from HIV Controllers Have Low Susceptibility to HIV-1 Infection In Vitro but High Capacity to Capture HIV-1 Particles. PLoS One 2016, 11:e0160251. 